\title{
STUDENTS' PERCEPTION TOWARD THE ENACTMENT OF METACOGNITIVE INSTRUCTION IN AN EFL WRITING CLASS: LESSON LEARNED FROM A PRIVATE UNIVERSITY IN INDONESIA
}

\author{
Ani Fiani \\ annie_fiani@yahoo.com \\ Department of English Education, STKIP PGRI Lubuklinggau, South Sumateria- \\ Indonesia
}

\begin{abstract}
Last five years has witness the crucial contribution of metacognitive pedagogy in EFL class. Yet, little has been paid this issue in the context of higher education. Thus, Last five years has witness the crucial contribution of metacognitive pedagogy in EFL class. Yet, little has been paid this issue in the context of higher education. . Thus, this article discussed the students' responses towards the use of the teaching program. This case study situated in a private university in Indonesia. The data were garnered from distributed questionnaire and reflective journal writing. The research results revealed that most of the EFL students had highly positive responses towards the implementation of metacognitive instruction in an EFL writing class including three aspects, namely the learning materials, learning activities, and benefits of the learning processes. Therefore, the teaching program had encouraged and benefited to the students in learning to write. Metacognitive instruction, as an alternative of effective methods, should be considered by teachers to help their students to become more independent learners.
\end{abstract}

Keywords: EFL, Metacognition, metacognitive instruction, writing

\section{Sari}

Metakognisi memainkan peranan penting dalam mengembangkan siswa menjadi pembelajar sukses yang mampu merencanakan tujuan pembelajaran mereka, memantau kemajuan belajar mereka, dan mengevaluasi hasil belajar mereka. Karena peranan penting metakognisi dalam pembelajaran bahasa, penerapan instruksi metakognitif dalam kelas menulis bahasa Inggris sebagai bahasa asing telah dilakukan selama satu semester. Untuk itu, artikel ini membahas tanggapan siswa terhadap penggunaan program pengajaran tersebut. Penelitian yang dilakukan terhadap tiga puluh tiga mahasiswa di sebuah perguruan tinggi swasta di Lubuklinggau ini menggunakan deskriptif kualitatif dengan pengumpulan data melalui kuisioner dan jurnal reflektif. Hasil penelitian menunjukkan bahwa sebagian besar siswa EFL memiliki respon yang sangat positif terhadap penerapan pembelajaran metakognitif di kelas menulis bahasa Inggris sebagai bahasa asing yang meliputi tiga aspek yaitu materi pembelajaran, 
kegiatan pembelajaran, dan manfaat proses pembelajaran. Oleh karena itu, program pengajaran ini telah mendorong dan memberikan manfaat kepada siswa dalam belajar menulis. Pengajaran metakognitif, sebagai alternatif metode yang efektif, harus dipertimbangkan oleh guru untuk membantu siswanya menjadi pembelajar yang lebih mandiri.

kata kunci: Metakognisi, instruksi metakognitif, menulis

Received 2020-09-07 accepted 2020-09-30 $\quad$ published 2020-09-30

APA Citation: Fiani, A. (2020). STUDENTS' PERCEPTION TOWARD THE ENACTMENT OF METACOGNITIVE INSTRUCTION IN AN EFL WRITING CLASS: LESSON LEARNED FROM A PRIVATE UNIVERSITY IN INDONESIA. Research and Innovation in Language Learning 3(3), pp. 220-233 http://dx.doi.org/10.33603/rill.v3i3.4105

\section{Introduction}

Nowadays, metacognition instruction plays a crucial role in improving language teaching and learning. For instance, Tarricone (2011) argues that metacognition is an important aspect to language learning. In contrast, teachers included in metacognition are preferable to assist their own and their students' development as stated by Fairbanks et al (2010) and Hattie (2012). Then, policymakers increasingly recognize the significance of metacognition, which they classify as a crucial competency for meeting future individual and global challenges (Griffin, McGaw, and Care, 2012). Moreover, according to van Velzen (2016) students who have good metacognition will become independent learners to learn of their own accord in the future effectively. Thus, it means that helping students construct language knowledge appears insufficient because they must also become active learners in the processing and memorization of information by making sense of their learning process.

Research also shows, for instance, that metacognition positively affects the effectiveness and quality of learning (Anderson, 2002, 2008; Chamot, 2004; Somaye and Shahla, 2016; Wenden, 1998), academic success (Zimmerman and Bandura, 1994), the improvement of student autonomy (Victori, 1999), and strategy use and selfregulated learning (Wenden, 1992). In the Indonesian context, the importance of metacognition to develop can be seen from one of the curriculum purposes in higher education that students should become autonomous learners in regulating or monitoring their learning in and beyond the classrooms (Permenristekdikti, 2015). Regarding this, 
EFL teachers, as facilitators or experts, should design their teaching programs more learner-centered learning processes. As educational experts and methodologists believe that teachers should train their students "how to learn," and thus they by themselves, using different techniques or strategies, plan, monitor, and evaluate their learning processes (Sardareh, Saad, and Boroomand, 2012). In short, students should be active and constructive in their learning, aware of their strengths and weaknesses, and learning strategies that they use to help them achieve their learning outcomes.

Regarding to EFL writing contexts, a study conducted by Fareed et al. (2016) found that students often faced difficulties in writing essays due to limited linguistic knowledge, anxiety, and lack of ideas, as well as L1 inferences and insufficient understanding of structure organization. One of the factors causing the writing problems is an ineffective use of strategies (Graham et al., 2000). Since teaching writing skills is still challenging in the EFL setting, teachers need to seek a revolutionary way to deal with it. Thus, Cohen and Macaro (2007) suggest that students need strategy-based practices to improve their writing abilities. As Zimmerman and Bandura's (1994) view, they stated that learning strategy use plays an essential role in maximizing students' knowledge and writing skills. Students should be taught the contextual, structural and educational principles of writing in a strategy-focused manner, taking into account student writing skills and competences (Sever, 2011, in Cer, 2019).

To overcome low proficient writers in Indonesia and by considering the importance of metacognition, a model of teaching-learning interaction is proposed in this research. It is metacognitive instruction (Joyce and Weil 1992; Pea et al., 2002 in Recee \& Walker, 2007, p. 58). The instruction encourages students to become more independent and autonomous (more able to plan, monitor and evaluate their learning process) and thus become efficient and successful students or, in other words, self-regulatory learners (Cer, 2019; Fenghua Lv, 2010; Goctu, 2017). Metacognitive learning activities, such as planning, monitoring, and evaluation, may assist students to improve and regulate awareness of linguistic and cognitive level for writing (Harris, Santangelo, and Graham, 2010). 
However, the implementation of metacognitive instruction has not been widely conducted in the Indonesian higher education setting, particularly in writing classes with less proficient students. Mbato (2013) investigated a metacognitive approach to facilitate self-regulation in reading classes in Universitas Sanata Dharma, Yogyakarta. The findings showed that the students' self-regulation in reading had significantly improved, particularly in personal and strategy aspects. They are more self-regulated in their learning to read, however, this study did not investigate the development of the students' reading comprehension. Moreover, Fiani (2018) conducted a case study related to the implementation of metacognitive instruction in EFL listening contexts during one semester. She found that the instruction improved the students' ability in learning to listen and benefited various effective strategies to help them becoming more successful language learners. Therefore, regarding to the implementation of metacognitive instruction in EFL writing, this article tried to investigate the students' responses towards the teaching program used in one semester in a private university in Lubuklinggau with thirty three students in the academic year of 2019/2020.

\section{Methods}

Enacting a descriptive case study, this study was conducted at a private university at Lingga during a semester of academic courses. This study attempted to describe the students' responses towards the implementation of metacognitive instruction in an EFL writing class in a private university during one semester. According to Malik and Hamied (2014, p.20) a descriptive study is focusing on gathering, managing, and summing up information on the issue under inquiry.

\section{Participants}

Thirty-three EFL students in the academic year of 2019/2020 were recruited and voluntarily participated in the study. Regardless to their sex identities due to ethics and negotiation consent, they aged around 19-22 year old. They have been learning English as their majors for over two years and categorized in intermediated level.

\section{Data collection and analysis}


To achieve the objective of the study, the researcher collected research data through distributing a questionnaire and reflective journals. Those research data then had been analyzed by considering three aspects of the implementation of the research program, namely learning materials, learning activities, and benefits of the learning processes.

\section{Results and Discussion}

This part discussed the students' responses to the teaching program. The program used in the research used a metacognitive approach proposed by Wenden (1992) and Harris et al. (2010). Then, in developing the instruction implemented in the classroom, the researcher used the CALLA approach designed by O'Malley and Chamot (1990) combined it into writing instruction. The researcher named it as metacognitive-based writing instruction.

The metacognitive-based writing instruction was implemented during one semester into 16 meetings. In each meeting, the students were encouraged to use several strategies to improve their writing abilities from planning to evaluation. The following part will present the students' responses toward the teaching program in nine statements. The students tried to respond to learning materials, learning activities, and benefits of the learning activities after they engaged in the teaching program during one semester into 16 meetings.

There were data collection tools, namely reflective journal, and questionnaire, prepared in order to investigate the students' opinions and to find out whether the implementation of metacognitive-based writing instruction was beneficial for them. The questions in the reflective journals included the process of writing as well as students' views on the metacognitive writing strategies before, during, and after the implementation. The questionnaire statements generally consist of the learning materials, learning activities, and the benefits of the teaching program.

\section{Students' responses to learning materials}

Regarding the learning materials, the students were asked several questions to reflect what they think about them. During the teaching program, there were several questions: 
1) do you think that the learning materials, descriptive and narrative texts, are relevant to the level of your capacities? 2) In your opinion, is the presentation of the learning materials systematic and easy to understand? 3) Do you think that the learning materials used are closely related to the real world?

Students 18 and S20 stated that their teacher's descriptive and narrative texts during the teaching program are relevant to their competencies in English. They learn step by step in writing descriptive and narrative paragraphs/essays. They enjoy learning to write those texts. Student 06, for example, stated that her teacher had systematically explained the learning materials so that she could easily follow and understand those materials. If she faced writing difficulties during the writing process, she did not doubt to ask her teacher.

Then, the majority of the students mentioned that the topics of the descriptive and narrative texts related to the real world. They described things, places, or people around them. They helped those students quickly developed their ideas in writing. Student 03, for instance, stated:

I am happy studying to write during the class. I can develop my ability. My teacher explains the materials systematically and easily to understand. I can write descriptive and narrative texts in paragraph and essay forms with selected topics. The topics are well-known by us because they are around us.

The students' responses on the teaching program's learning materials are summarized in the following table.

Table 4.1.: students' responses on learning materials

\begin{tabular}{llll}
\hline No. & Statements & Agree & Disagree \\
\hline 1. & $\begin{array}{l}\text { The materials in the teaching program are relevant to the level of } \\
\text { students' abilities. }\end{array}$ & $100 \%$ & \\
\hline 2. & $\begin{array}{l}\text { The presentation of the learning materials is systematic and easy to } \\
\text { understand. }\end{array}$ & $100 \%$ \\
\hline 3. & The learning materials used are closely related to the real world. & $100 \%$ \\
\hline
\end{tabular}

The percentage of students indicates that the teaching materials, narrative and descriptive texts, used in the teaching program were relevant to the level of their abilities, systematic and easy to understand, and closely related to the real world. All of the students $(100 \%)$ agreed to the statements after implementing the metacognitivebased writing instruction during one semester. 
Learning materials play a crucial role in language teaching and learning. They are tools that are applied to facilitate learning and understanding of concepts, particularly a writing subject. Based on the research results above, the students had good responses towards the learning materials in learning to write effectively and efficiently. The materials had motivated them in mastering their writing skills. They were meaningful for the students. It is in line with Busljeta's (2013) statement that one of objectives of teaching and learning materials is motivating learners. Therefore, the materials used in this study were relevant, systematic, easy, and closely correlated to the facts.

\section{Students' responses to learning activities}

Regarding learning activities in the teaching program, the students had been asked several questions in their journals such as 1) did you apply metacognitive writing strategies before this teaching program? 2) Do you now apply the planning activities before the writing task? 3) Do you now apply the monitoring activities while the writing task? 4) Do you now apply the evaluation activities after the writing task?

Metacognitive writing strategies are new for the majority of the students. They stated that they did not know about the strategies before the teaching program. However, some of them mentioned that they have ever implemented those strategies, although they did not know the name. Student 19, for example, argued:

I am not familiar with the name of metacognitive strategies before. It is the new one for me. However, I have been using some strategies, although I don't know that it was called metacognitive writing strategies. Now, after implementing the strategies, I make writing paragraphs and essays easier and more fun. (Refl.05)

In the planning phase, most of the students argued that they did planning activities before writing a text. The planning stage helped them in organizing their texts. Student 11, for instance, stated:

When my lecturer asked me to write a descriptive text. I try to plan it by using an outline strategy to organize my writing. This activity is important to help me in arranging the text and see the whole picture of my writing before I make a draft (Refl.03). 
Then, in the monitoring stage, most of the students stated that they tried to read and check their rough drafts. They do those activities after they finish writing each sentence in making a paragraph and each paragraph in making an essay. Student 29, for example, mentioned:

Yes, I check my draft by looking at my plan whether it followed the outline or not. Sometimes I stop and recheck what I have done and what is still needed to be done (Refl.3).

Moreover, most of the students stated that they tried to apply evaluating strategies after they had written a text. After finishing their draft, they evaluate it step by step from content and organization, as well as sentence construction and vocabulary. Student 13, for instance, said:

Yes, I use the assessment stage after writing a descriptive essay. I evaluate my draft by reading and check the content, organization, and grammar as far as I know. Sometimes if I doubt that my writing is good enough or not, I asked my classmate to check and comment it. Now I know how to use it efficiently and effectively.

Furthermore, the students' survey responses on learning activities implemented during one semester through metacognitive instruction are summarized in Table 17 below.

Table 4.2: Students' survey responses regarding learning activities

\begin{tabular}{llcc}
\hline No. & Statements & Agree & Disagree \\
\hline 1. & The learning instructions used are clear and easy to understand. & $100 \%$ & \\
\hline 2. & $\begin{array}{l}\text { The learning activities used to make it easier for students to } \\
\text { learn writing skills. }\end{array}$ & $100 \%$ & \\
\hline
\end{tabular}

The students' responses related to learning activities used in the teaching program were shown in two statements. Based on the statements, all of the students (100\%) agreed that the learning instruction used was clear and easy to understand. The instruction also made it easier to learn writing skills. During one semester, they used various effective writing strategies from planning, regulating, and evaluating their learning performance. Those strategies are included in metacognitive strategies. Various experts argue that those strategies are needed to master by EFL students so that they are more selfregulated and successful language learners (Anderson, 2002, 2008; Chamot, 2004; Somaye and Shahla, 2016; Wenden, 1992, 1998; Zimmerman and Bandura, 1994). In 
conclusion, the learning instructions used in this study were easy and clear to follow, use, and engage in the teaching and learning process.

\section{Students' responses to the benefits of learning activities}

Regarding the benefits of learning activities, the teacher asked the students to reflect on the use of metacognitive strategies. There were several questions, such as 1) did metacognitive writing strategies that help you write paragraphs and essays? 2) What are your perceptions of the impact of the metacognitive writing strategies on your performance? 3) How did you benefit from pair and group work in the process of writing? 4) Are organization, planning, and the use of cohesive devices necessary during the writing process for you? 5) Name three things that you gained due to metacognitive writing strategies? 6) Did you have any problems while learning to use metacognitive strategies and applying them?

The metacognitive writing strategies helped most of the students in learning to write paragraphs and essays. The strategies allowed them to plan, monitor, and evaluate their writing processes so that they did not need to rewrite the texts several times. Student 05, for example, stated:

I am happy in learning to write by using metacognitive writing strategies. It helped me to write systematically and efficiently. I didn't need to rewrite my draft several times. It saves my time. I also can write independently. In planning phase, I could expand my background knowledge to support my writing. Then, in monitoring phase, I could generally read and check my draft and evaluate it after I finished my writing (Refl.5).

The student's statement regarding the impact of the metacognitive strategies on their writing performance showed positive responses. They argued that after engaging in the teaching program during one semester, they got many positive effects such as they could manage their own learning not only in but also outside the classroom; they were aware that those strategies helped them not only in writing but also self-study in general; they felt confident in writing good texts. Student 16, for example, mentioned:

I believe that metacognitive writing strategies are useful and meaningful for me. I can use them in writing to improve my performance. Although using those 
strategies is time-consuming and a little bit stressful, but in fact, it is worth it. I felt confident, and I am sure I will get a good grade in this subject (Refl.5).

Considering the benefits of pair and group work in the writing process, the students stated that they got new supports in learning to write. They could learn together and ask their friends if they faced problems during the process. Student 11, for instance, said:

Working in pairs and group works made me happy and enjoyed learning in this class. I can share my knowledge, and if I have some problems, I can ask them. I felt my confidence increasing well. Although the objective of metacognitive writing strategies is independently used by me, working together can help me in developing the strategies. We can support each other (Refl.5).

Next, most of the students were aware that the use of cohesive devices, organization, and planning played a crucial role in the writing process. They stated that planning and organizing are critical factors in writing. Those helped them in arranging and developing their ideas before they made a draft. Moreover, they also mentioned what they gained from metacognitive writing strategies implemented during the teachinglearning processes of writing for general communication, particularly descriptive and narrative texts. Generally, they stated that they could write accurately and effectively, broaden their knowledge of the paragraphs and essays, and organize their thoughts in advance. Student 17 , for instance, mentioned:

By using metacognitive writing strategies, I can make my writing more accurate. I can better express myself and activate my background knowledge while writing. These strategies are meaningful and enjoyable activity (Refl.5).

Even though the majority of the students stated positively regarding metacognitivebased writing instruction, they faced many difficulties in using planning, monitoring, and evaluating strategies. They mentioned that those activities initially seemed undoable and formalistic, unsurmountable, and boring as well. However, in the last sections, they felt better and enjoyed using the strategies. The survey also asked the students whether they elicit the benefits of the learning activities after they engaged in the teaching program during one semester. The findings of these four statements are summarized in the following table.

Table 4.3: Students' responses on the benefits of learning activities

\begin{tabular}{llll}
\hline No. Statements & Agree & Disagree \\
\hline
\end{tabular}


1. The learning activities in the teaching program are beneficial for $100 \%$ students.

2. The learning activities in the teaching program improve students' $97 \% \quad 3 \%$ abilities in writing.

3. The learning activities in the teaching program motivate students to $97 \% \quad 3 \%$ learn to write.

4. The learning activities in the teaching program allow students to $94 \% \quad 6 \%$ use them independently outside of the classroom.

The data indicates that the implementation of metacognitive-based writing instruction during one semester provided many benefits. Regarding statement 1 , all of the students $(100 \%)$ agreed that the learning activities in the teaching program were beneficial. They knew that the teaching instruction helped them to learn effectively in writing. Then, 97\% of the students agreed that metacognitive instruction activities improved their writing abilities. Moreover, most of them (97\%) agreed that after they engaged in the teaching program during one semester, the instruction motivated them to learn to write. Finally, regarding the statement $4,94 \%$ of the students argued that the learning activities allowed them to use the learning strategies independently outside of the classroom.

Metacognitive strategies used in this study helped the students to become more selfregulated and successful learners. Wenden (1987) explain that successful FL / SL students know how to prepare, manage, concentrate and use a variety of techniques to solve challenges and assess their language learning performances. Therefore, through the teaching program, the students elicited many benefits for their own learning to become more independent students. Overall, the students' responses and reflective journals revealed that most of the students positively elicited many benefits from the teaching program during one semester. The questionnaire was divided into three categories, namely learning materials, learning activities, and benefits of the learning activities. The results showed that most of the students positively responded to the teaching program during one semester.

\section{Conclusion \& recommendation}

The important role of metacognition has been considered by many language researchers. They have been aware that this ability can help language learners to become more self- 
regulated and successful learners. The students are able to become independent learners in planning, monitoring, and assessing their own learning inside and outside the classroom. Thus, the researcher implemented metacognitive instruction in teaching writing and tried to find out the students' responses towards the instruction. The research results have been divided into three aspects, namely the learning materials, the learning activities, and the benefits of the learning processes and showed that most of the students positively responded to the teaching program. They elicited many benefits to help them becoming independent and successful learners who are able to set their learning goals, monitor their learning progress, and assess their learning performance, particularly in writing.

For further researchers, although this research results could not be generalized, the implementation of metacognitive instruction in teaching writing indicated that there was a positive response to be considered by EFL teachers. They are able to use it as an alternative language teaching instruction in facilitating their students in mastering English. Moreover, the further researchers can conduct a research with more respondents, other language skills, or other language settings.

\section{References}

Anderson, N. (2002). The role of metacognition in second language teaching and learning. ERIC Digest, EDO-FL-01-10, 1-2.

Anderson, N. J. (2008). Metacognition and Good language learners. In C. Griffiths, Lessons from Good language learners (pp.99-110). New York: Cambridge.

Busljeta, R. (2013). Effective use of teaching and learning resources. Czech-Polish historical and pedagogical journal, 5(2), pp.55-69. Retrieved from July 20, 2019 from https://www.ped.muni.cz/cphpjournal/520132/06.pdf

Chamot, A. U. (2004). Issues in language learning strategy research and teaching. Electronic Journal of foreign language teaching, 1(1), 14-26.

Cher, E. (2019). The Instruction of writing strategies: the effect of the metacognitive strategy on the writing skills of Pupils in secondary education. SAGE Open, 117.

Cohen, L., Manion, L., \& Morrison, K. (2007). Research methods in education (6th ed.). New York, NY: Routledge.

Fairbanks, C., Duffy, G. G., Faircloth, B., He, Y., Levin, B. B., Rohr, J., \& Stein, C. (2010). Beyond knowledge: exploring why some teachers are more thoughfully adaptive than others. Journal of Teacher Education, 61, January, 161-171.

Fareed, M., Ashraf, A., \& Bilal, M. (2016). ESL learners' writing skills: problems, factors, and suggestions. Journal of education and social sciences, 4(2), pp. 8192. 
Fenghua Lv and Chen, H. (2010). A study of metacognitive-strategies-based writing instruction for vocational college students. English language teaching, 3(3), 136-144.

Fiani, A., Suherdi, D., \& Musthofa, B. (2018). The impact of metacognitive instruction on EFL students' listening comprehension and metacognitive awareness in Lubuklinggau. Advances in Social Science, Education and Humanities Research (ASSEHR), 188, pp. 134-140.

Goctu, R. (2017). Metacognitive strategies in Academic writing. Journal of Education in Black Sea Region, 2(2), 82-95.

Graham, S., Harris, K. R., \& Fink-Chorzempa, B. (2000). Is handwriting casually related to learning to write: treatment of handwriting problems in beginning writers. Journal of Educational psychology, 92, pp.620-633.

Griffin, P., McGaw, B., \& Care, E. (2012). The changing role of education and schools. In P. Griffin, B. McGaw, \& E. Care (Eds.), Assessment and teaching of $21^{\text {st }}$ century skills (pp.1-16). Dordrecht, Germany: Springer science + Business Media B.V.

Harris, K. R., Santangelo, T., \& Graham, S. (2010). Metacognition and strategies instruction in writing. In H. S. Waters \& W. Scheneider (Eds.), Metacognition, strategy use, and instruction (pp. 226-256). New York, NY: The Guilford Press.

Hattie, J. A. C. (2012). Visible learning for teachers. London: UK: Routledge.

Joyce, B., \& Weil, M. (1992). Models of teaching. New York: Allin and Bacon.

Malik, R. S., \& Hamied, F.A. (2014). Research Methods: A Guide for First Time Researchers. Bandung: UPI Press.

Mbato, C. L. (2013). Facilitating EFL learners' self-regulation in reading: implementing a metacognitive approach in an Indonesian higher education context. Unpublished Dissertation. Lismore, NSW: Southern Cross University.

O’Malley, J. M., \& Chamot, A. U. (1990). Learning strategies in second language learning. Cambridge: Cambridge University Press.

Permenristekdikti. (2015). Standar Nasional Pendidikan Tinggi. No. 44, 2015.

Recee, I., \& Walker, S. (2007). Teaching, training, and learning ( $6^{\text {th }} E d$.). Sunderland: Business Education Publishers Ltd.

Sardareh, S.A., Saad, M.R.M., \& Boroomand, R. (2012). Self-regulated learning strategies and academic achievement in pre-university EFL learners. California Linguistic Notes, 37(1), 1-35.

Somaye, S. \& Shahla, S. (2016). The relationship between metacognitive and selfregulated learning strategies with learners' L2 learning achievement. International Journal of Research Studies in Language Learning. 5(2), 97-106.

Tarricone, P. (2011). The taxonomy of metacognition. New York: Psychology Press.

VanVelzen, J. (2016). Metacognitive learning: advancing learning by developing general knowledge of the learning process. Switzerland: Springer International Publishing.

Victori, M. (1999). An analysis of writing knowledge in EFL composing: A case study of two effective and two less effective writers. System, 27(4), 537-555. https://doi.org/10.1016/S0346-251X(99)00049-4.

Wenden, A. (1987). Metacognition: An expanded view in the cognitive abilities of L2 learners. Language Learning, 37(4), 573-597.

Wenden, A. (1992). Learner strategies of Learner Autonomy. New York: Prentice Hall. 
Wenden, A. L. (1998). Metacognitive knowledge and language learning. Applied linguistics, 19(4), 515-537. https://doi.org/10.1093/applin/19.4.515.

Zimmerman, B., and Bandura, A. (1994). Impact of self-regulatory influences on writing cource attainment. American Educational Research Journal, 31, 845862.

\title{
Conflict of Interest
}

No potential conflict of interest is reported

\begin{abstract}
About author
Ani Fiani works at English Education Study Program of STKIP-PGRI Lubuklinggau, South Sumatera. She gained her master degree from Sebelas Maret University (UNS) in 2012 and is currently pursuing doctoral degree in Universitas Pendidikan Indonesia (UPI). Her interests are mainly in the area of English language teaching (ELT), EFL Curriculum Development. She can be reached via email, annie_fiani@yahoo.com
\end{abstract}

http://orcid.org/0000-0002-2835-1123 